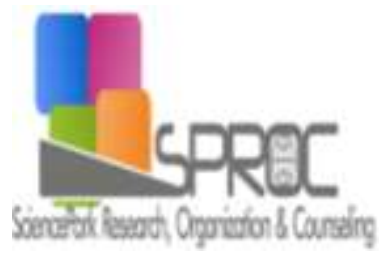

\section{New Trends and Issues Proceedings on Humanities and Social Sciences}

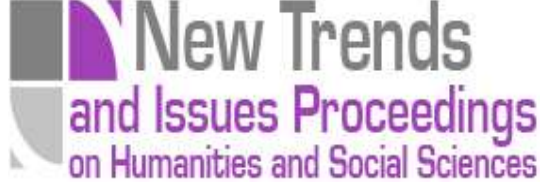

ISSN 2421-8030

www.prosoc.eu

Selected Papers of 1st International Congress on Nursing (ICON-2017) 16 - 18 March 2017 Grand Park Lara Convention Center, Lara - Antalya, Turkey

\title{
The effect of aromatherapy on pain, comfort and satisfaction during childbirth
}

Zehra Cenkci a *, Department of Nursing, Faculty of Health Sciences, Cukurova University, 01000, Adana, Turkey. Evsen Nazik ${ }^{\text {b }}$, Department of Nursing, Faculty of Health Sciences, Cukurova University, 01000, Adana, Turkey.

\section{Suggested Citation:}

Cenkci, Z. \& Nazik, E. (2017). The effect of aromatherapy on pain, comfort and satisfaction during childbirth.

$$
R \quad \text { [Online]. 4(2), pp 11-19. Available from: }
$$

www.prosoc.eu

Selection and peer review under responsibility of Prof. Dr. Nesrin Nural,

${ }^{\circ} 2017$ SciencePark Research, Organization \& Counseling. All rights reserved.

\begin{abstract}
Research was conducted in order to identify the effect of aromatherapy on pain, comfort and satisfaction during the first stage of childbirth, using a randomized controlled, quasi-experimental trial with control group.Study was conducted between 01.06.2016-02.08.2016 at the delivery room of Republic of Turkey, Ministry of Health, Public Hospitals Administration, Adana Gynaecology and Paediatrics Hospital. The sample of the study was a total of 60 pregnant women who were admitted to the delivery room for vaginal delivery between the abovementioned dates and fit the participation criteria, and 30 of these women were in the control group whereas 30 were in the experimental group. For data collection, "Personal Information Form", "Visual Analog Scale (VAS)", "Chıldbırth Comfort Scale (CCS)" and "Postpartum Self-Assessment Scale"s "Satisfaction with Childbirth" sub-dimension were used. For data evaluation, percent distributions, chisquare significance test, independent samples t-test and Mann-Whitney $U$ test were used. In the Latent phase of childbirth, mean VAS was $3,4 \pm 2,1$ in experimental group, $6,6 \pm 2,0$ in control group; in the Active phase of childbirth, mean VAS was $6,1 \pm 1,7$ in experimental group, $8,7 \pm 1,0$ in control group; in the Transition phase, mean VAS was 8,3 $\pm 0,9$ in experimental group, and 9,8 $\pm 0,5$ in control group, and the difference between groups was significant in all phases $(p=0.000)$. In the Latent phase of childbirth, mean CCS points was $3,4 \pm 2,1$ in experimental group, $6,6 \pm 2,0$ in control group; in the Active phase of childbirth, mean CCS points was $6,1 \pm 1,7$ in experimental group, $8,7 \pm 1,0$ in control group; in the Transition phase, mean CCS points was 8,3 $\pm 0,9$ in experimental group, and 9,8 $\pm 0,5$ in control group, and the difference between groups was significant in all phases $(p=0.000)$. Mean value of Satisfaction with Childbirth points was $30,03 \pm 2,53$ for the experimental group and $27,6 \pm 3,6$ for the control group, and the difference was statistically significant $(p=0.000)$.In this study, aromatherapy was found to reduce the perception of pain and increase the level of comfort and satisfaction during the first stage of childbirth. These results show that aromatherapy is a nursing intervention that is efficient in coping with labour pain and increasing the level of comfort and satisfaction.
\end{abstract}

Keywords: Aromatherapy; labour pain; comfort; satisfaction; nursing.

* ADDRESS FOR CORRESPONDENCE: Zehra Cenkci, Department of Nursing, Faculty of Health Sciences, Cukurova University, 01000, Adana, Turkey. 


\section{Introduction}

It can be seen that in recent years, non-pharmacological methods of reducing labor pain became the focus, and the tendency towards complementary/alternative medicine during labor increased (Brown, Douglas \& Plaster Flood, 2001; Munoz Selles, Valles-Segales \& Goberna-Tricas, 2013). Aromatherapy is one of the most widely used complementary/alternative treatment modalities in nursing practice (Marzouk, El-Nemer \& Baraka, 2013). Aromatherapy is defined as the utilization of the healing powers of plant-sourced essential oils to balance and treat the individual mentally, physically, and spiritually (Tournaire \& Theau Yonneau, 2007; Smith, Collins \& Crowther, 2011). In the literature, aromatherapy is reported to maintain physical and spiritual equilibrium, provide relaxation, reduce anxiety, fear, pain, and increase the feeling of well-being in humans. In the study by Burns et al. (2000), aromatherapy is found to be effective in reducing maternal anxiety, fear and/or pain during labor (Burns, Blamey, Ersser, Lloyd \& Barnetson, 2000). In another study on using aromatherapy at birth, $38 \%$ of women stated that they use aromatherapy to cope with pain, $30 \%$ to reduce anxiety, $18 \%$ to prevent fear, and $14 \%$ to expedite delivery (Burns, Zobbi, Panzeri, Oskrochi \& Regaliab, 2007). In a study which stated that anxiety and stress increases the perceived pain during labor, aromatherapy was reported to help decreasing the anxiety during labor (Tillett \& Ames, 2010). In Karabulut's (2014) study on the effects of aromatherapy during labor, it was identified that aromatherapy reduces the perceived pain during labor, reduces the level of trepidation and anxiety, increases the woman's pain tolerance and confidence, and reduces the duration of labor. In the same study, no maternal and fetal side effects associated with aromatherapy treatments were observed (Karabulut, 2014). Rashidi-Fakar et al. (2015) found that orange scent is a non-invasive method effective on anxiety during labor (Rashidi Fakari, Tabatabaeichehr \& Mortazavi, 2015). In another randomized-controlled study on the effects of aromatherapy, it was reported that geranium essential oil can be effective in reducing anxiety during labor (Rashidi Fakari, Tabatabaeichehr, Kamali, Rashidi Fakari \& Naseri, 2015). Although there is a limited number of evidence-based studies on nonpharmacological methods, as a result of these studies, it was found that non-pharmacological methods are regarded as comfortable by mothers and make mothers content (Yilar-Erkek \& Pasinlioglu, 2016; Mamuk \& Davas, 2010).

Pain during labor has a negative effect on comfort, and reducing pain during the course of the labor means providing satisfaction (Schuiling, Sampslelle \& Kolcaba, 2011). Moreover, providing comfort to the woman is largely associated with providing satisfaction. Birth satisfaction is important for the health of mother and child, and is a factor which has positive influence on the next labor (Goodman, Mackey \& Tavakoli, 2004). Nurses, who are important members of the team of health professionals, should help women in coping with the labor pain, provide comfort, and provide a satisfactory labor experience by using non-pharmacological methods (Pinar, Dogan, Algier, Kaya \& Cakmak, 2009). Research hypotheses of the study are as follows:

HO: Aromatherapy does not affect the level of pain, comfort and satisfaction during labor.

$\mathrm{H} 1$ : Using aromatherapy during labor reduces the woman's perception of pain at labor, increases the level of comfort and satisfaction.

\section{Materials and Methods}

\subsection{Study design}

A randomized-controlled study was performed in Maternity and Pediatric Diseases Hospital between 01.06.2016-02.08.2016. 


\subsection{Setting and sample}

The research included women aged between 18-35 years, primipara, with 38-42 weeks of singleton pregnancy, had spontaneously begun labor, in the latent phase of the first stage of labor, with occiput anterior presentation, did not receive epidural analgesia, with a risk-free pregnancy, no indications for caesarean, did not attend childbirth classes, do not have any problems with scents, are not allergic to lavender (Lavandula angustifolia Mill.), with no communicative problems.

In the power analysis performed using GPower 3.1, sample size calculated using $80 \%$ power and alpha $=0,05$ and student t-test was 11 for each group, with a total of 22 . Considering the probability of women leaving the study, the study was conducted with 62 people (32 intervention, 30 control). Two participants of the intervention group were excluded from the study due to non-progressive labor and fetal distress. The study was completed with 60 women (30 intervention, 30 control).

Randomization was performed in the study. The total number of samples to be included in the study was identified based on the groups, from the random number list on the computer. This randomization list was written on papers and placed in the envelopes with the same number written on them. When the women who fit the sample criteria arrived at the delivery room, the group they belong was determined according to the envelopes.

\subsection{Instruments}

For data collection, "Personal Information Form", "Visual Analog Scale (VAS)", "Childbirth Comfort Questionnaire", and "Satisfaction with Childbirth" subdimension of "Postpartum Self-Assessment Scale" were used.

$R \quad f f \quad$ is composed of questions including socio-demographic and obstetric characteristics of pregnant women.

includes numbers from 0 to 10 on a $100 \mathrm{~mm}$ line. Pain intensity is represented by numbers ranging from 0 to 10; absence of pain is indicated by ' 0 ' and the most severe pain is indicated by ' 10 '. In the evaluation of VAS, the description is as follows: $0 \mathrm{~cm}=$ no pain, $0.5-3 \mathrm{~cm}=$ mild pain, 3.5-6.5 cm=moderate pain, 7-10 cm=severe pain (Yildirim \& Hotun-Sahin, 2004).

$i \quad i \quad f f \quad$ was developed by Kerri Durnell Schuiling in 2003 and influenced by Kolcaba's theory of comfort. In the study by Schuiling, Sampslelle and Kolcaba, the questionnaire was applied to 64 pregnant women (Schuiling, Sampslelle \& Kolcaba, 2011). The Cronbach's alpha of the questionnaire is 0.71 , and as the result of the factor analysis, 4 factors, named as physical, environmental, psychospiritual and sociocultural, were identified. Turkish validity reliability was done by Potur et al. in 2015 (Potur-Coskuner, Merih, Kulek \& Gurkan, 2015). The questionnaire is 5-point likert-type and has 9 items and 3 subdimensions (Physical, Spiritual, and Environmental subdimension). The minimum possible score of the questionnaire is 9 , and the maximum possible score is 45 . As the scores increase, comfort level is high, and as the scores decrease, comfort level is low. Cronbach's alpha coefficient of the questionnaire is $\alpha=.75$, and the Cronbach's alpha coefficients of the subdimensions vary between $\alpha=.51-.71$. In this study, Cronbach's alpha coefficient of the intervention group is $\alpha=.70$, and $\alpha=.75$ for the control group.

ff $\quad i \quad i \quad i \quad f f R \quad r \quad$ ff $\quad$ postpartum selfassessment scale was developed by Lederman and Weingarten in 1981. Turkish validity reliability was done by Beydag and Mete in 2007. The scale has 7 subdimensions and 82 items of 4-point likert-type. Satisfaction with Childbirth subdimension comprises 10 items (items 6, 9, 28, 47, 48, 58, 67, 68, 73 and 79 ), and its 6 items (items 6, 9, 47, 67, 73, and 79) are reversely scored. The minimum possible score of the scale is 10 , and the maximum possible score is 40 . High score indicates low level of satisfaction with the childbirth experience. The Cronbach's alpha value of the total scale is 0.87 , and the Cronbach's alpha value of the Satisfaction with Childbirth subdimension is 0.76 (Tasci \& Mete, 2007). In this study, Cronbach's alpha coefficient of the intervention group is $\alpha=.70$, and $\alpha=.68$ for the control group. 


\subsection{Data collection}

The study was conducted using two groups: intervention and control.

Intervention group (lavender oil inhalation): Face-to-face interviews with women were conducted and personal information forms were filled, aromatherapy was performed in addition to routine nursing care. Aromatherapy was performed using taper (attachment of the cloth containing the essential oil to woman's clothes). Taper was performed by renewing one drop of essential oil once an hour during the course of labor. In the study, Nurs Lokman Hekim brand lavender oil, approved by Turkish Food Codex, was used. Visual Analog Scale (VAS) and Childbirth Comfort Questionnaire were assessed at the latent $(3-4 \mathrm{~cm})$, active $(5-7 \mathrm{~cm})$, and transition (8-10) phases of the labor. In early postpartum period, Childbirth Comfort Questionnaire was performed in regular maternity ward.

Control Group: Face-to-face interviews with women were conducted and personal information forms were filled, and routine nursing care was provided. Visual Analog Scale (VAS) and Childbirth Comfort Questionnaire were assessed at the latent $(3-4 \mathrm{~cm})$, active $(5-7 \mathrm{~cm})$, and transition $(8-10)$ phases of the labor. In early postpartum period, Childbirth Comfort Questionnaire was performed in regular maternity ward. Data collection process is shown in Appendix.

\subsection{Data analysis}

Statistical analysis was performed using SPSS version 16.0 software (SPSS Inc., Chicago, IL, USA). Descriptive data were expressed in mean and standard deviation (SD). The chi-square, Mann-Whitney $\mathrm{U}$, and t-tests (independent groups) were performed. A $r$ value of 0.05 with $95 \%$ confidence interval was considered statistically significant.

\subsection{Ethical consideration}

The School of Medicine institution review board reviewed and approved the study protocol in 2016. First, the women included in the study were informed about the purpose of the study. They were also informed that the information collected on the issue would not be read by anybody apart from the researchers, and that the information would be used for scientific purposes and, in this way, their verbal permission was taken.

\section{Results}

The mean age of the intervention (I) and control (C) groups were 22,0 $\pm 2,8$ and 23,6 $\pm 4,1$, respectively, and the majority were primary school graduates (I: 53,4\%, C:56,7\%), did not work (I: $86,7 \%, C: 93,3 \%$ ), in moderate economic conditions (I: $83,4 \%, C: 93,4 \%$ ), and had nuclear family (I: $60 \%$, $\mathrm{C}: 76,7 \%)$. Socio-demographically, the difference between groups was not statistically significant $(p>0,05)$.

The mean pregnancy 
Table 1. Comparison of the VAS Points at the First Stage of Labor

\begin{tabular}{|c|c|c|c|}
\hline 1st Stage of Labor & $\begin{array}{l}\text { Intervention Group } \\
\qquad \begin{array}{l}\text { Mean } \\
\bar{x} \pm \mathrm{SD}\end{array}\end{array}$ & $\begin{array}{l}\text { Control Group } \\
\begin{array}{l}\text { Mean } \\
\bar{x} \pm \mathrm{SD}\end{array}\end{array}$ & Analysis \\
\hline Latent phase & & & $M W-U=113,000$ \\
\hline$(3-4 \mathrm{~cm})$ VAS & $3,4 \pm 2,1$ & $6,6 \pm 2,0$ & $p=0,000$ \\
\hline Active phase & & & $M W-U=79,000$ \\
\hline$(5-7 \mathrm{~cm})$ VAS & $6,1 \pm 1,7$ & $8,7 \pm 1,0$ & $p=0,000$ \\
\hline $\begin{array}{l}\text { Transition phase } \\
(8-10 \mathrm{~cm}) \text { VAS }\end{array}$ & $8,3 \pm 0,9$ & $9,8 \pm 0,5$ & $\begin{array}{c}M W-U=80,000 \\
p=0,000\end{array}$ \\
\hline
\end{tabular}

The mean of the total score of Childbirth Comfort Questionnaire at the Latent Phase of Labor for the intervention group was $37,1 \pm 4,4$, and it was $30,2 \pm 4,4$ for the control group and the difference between groups was statistically significant (Table 2 ).

Table 2. Comparison of the Mean Childbirth Comfort Questionnaire (CCQ) and Subdimension Scores at the Latent Phase of Labor

\begin{tabular}{ccccc}
\hline $\begin{array}{c}\text { CCQ and } \\
\text { Subdimensions }\end{array}$ & $\begin{array}{c}\text { Possible scores } \\
\text { Min-Max }\end{array}$ & $\begin{array}{c}\text { Intervention } \\
\text { Group } \\
\bar{x} \pm \text { SD }\end{array}$ & $\begin{array}{c}\text { Control Group } \\
\bar{x} \pm \text { SD }\end{array}$ & Analysis \\
\hline $\begin{array}{c}\text { Physical Role } \\
\text { Subdimension }\end{array}$ & $4-20$ & $16,6 \pm 1,9$ & $13,1 \pm 2,3$ & $\begin{array}{c}\mathrm{MW}-\mathrm{U}=111,000 \\
\mathrm{p}=0,000 \\
\mathrm{MW}-\mathrm{U}=187,000 \\
\mathrm{p}=0,000\end{array}$ \\
$\begin{array}{c}\text { Psychospiritual } \\
\text { Subdimension }\end{array}$ & $2-10$ & $8,1 \pm 1,7$ & $6,4 \pm 1,4$ & $\mathrm{MW}-\mathrm{U}=242,000$ \\
$\begin{array}{c}\text { Environmental } \\
\text { Subdimension }\end{array}$ & $3-15$ & $12,4 \pm 2,2$ & $10,7 \pm 1,9$ & $\mathrm{p}=0,000$ \\
Toplam CCQ & $9-45$ & $37,1 \pm 4,4$ & $30,2 \pm 4,4$ & $\mathrm{MW}-\mathrm{U}=120,500$ \\
$\mathrm{p}=0,000$
\end{tabular}

For the intervention group, the mean of the total score of Childbirth Comfort Questionnaire at the Active Phase of Labor was $36,3 \pm 3,2$, and for the control group, it was $25,3 \pm 4,6$, and the difference between groups was statistically significant $(p<0.05)$ (Table 3$)$. 
Table 3. Comparison of the Mean CCQ and Subdimension Scores at the Active Phase of Labor

\begin{tabular}{|c|c|c|c|c|}
\hline $\begin{array}{c}\text { CCQ and } \\
\text { Subdimensions }\end{array}$ & $\begin{array}{l}\text { Possible scores } \\
\text { Min-Max }\end{array}$ & $\begin{array}{c}\text { Intervention Group } \\
\bar{x} \pm \mathrm{SD}\end{array}$ & $\begin{array}{c}\text { Control Group } \\
\bar{x} \pm \mathrm{SD}\end{array}$ & Analysis \\
\hline $\begin{array}{l}\text { Physical Role } \\
\text { Subdimension } \\
\text { Psychospiritual } \\
\text { Subdimension }\end{array}$ & $4-20$ & $\begin{array}{c}15,9 \pm 1,8 \\
7,7 \pm 1,0\end{array}$ & $\begin{array}{l}10,5 \pm 2,7 \\
5,0 \pm 1,3\end{array}$ & $\begin{array}{c}M W-U=51,000 \\
p=0,000 \\
M W-U=51,000 \\
p=0,000\end{array}$ \\
\hline $\begin{array}{l}\text { Environmental } \\
\text { Subdimension }\end{array}$ & $3-15$ & $12,6 \pm 1,8$ & $9,8 \pm 1,7$ & $\begin{array}{c}M W-U=120,500 \\
p=0,000 \\
M W-U=32,000\end{array}$ \\
\hline Toplam CCQ & $9-45$ & $36,3 \pm 3,2$ & $25,3 \pm 4,6$ & $p=0,000$ \\
\hline
\end{tabular}

When the mean CCQ points at the transition phase of labor were compared, the mean of the total score of the intervention group was $33,6 \pm 3,9$, and of the control group, it was $21,1 \pm 4,7$, and the difference between groups was statistically significant $(p<0,05)$ (Table 4$)$.

Table 4. Comparison of the Mean CCQ and Subdimension Scores at the Transition Phase of Labor

\begin{tabular}{|c|c|c|c|c|}
\hline $\begin{array}{c}\text { CCQ and } \\
\text { Subdimensions }\end{array}$ & $\begin{array}{l}\text { Possible scores } \\
\text { Min-Max }\end{array}$ & $\begin{array}{l}\text { Intervention Group } \\
\qquad \bar{x} \pm \mathrm{SD}\end{array}$ & $\begin{array}{c}\text { Control Group } \\
\bar{x} \pm \mathrm{SD}\end{array}$ & Analysis \\
\hline Physical Role & & & & $\mathrm{MW}-\mathrm{U}=69,500$ \\
\hline Subdimension & $4-20$ & $14,3 \pm 2,6$ & $8,1 \pm 3,0$ & $p=0,000$ \\
\hline $\begin{array}{l}\text { Psychospiritual } \\
\text { Subdimension }\end{array}$ & $2-10$ & $7,1 \pm 1,1$ & $4,3 \pm 1,3$ & $\begin{array}{c}M W-U=59,500 \\
p=0,000\end{array}$ \\
\hline $\begin{array}{l}\text { Environmental } \\
\text { Subdimension }\end{array}$ & $3-15$ & $12,2 \pm 1,5$ & $8,8 \pm 1,8$ & $\begin{array}{c}M W-U=78,000 \\
p=0,000\end{array}$ \\
\hline Total CCQ & $9-45$ & $33,6 \pm 3,9$ & $21,1 \pm 4,7$ & $\begin{array}{c}M W-U=32,500 \\
p=0,000\end{array}$ \\
\hline
\end{tabular}

When the mean scores of the groups from the Satisfaction with Childbirth Scale are compared, the mean scores of the intervention group was $27,6 \pm 3,6$, and the mean points of the control group was $30,03 \pm 2,53$, and the difference between groups was statistically significant $(p<0,05)($ Table 5$)$.

Table 5. Comparison of the Mean Scores from Satisfaction with Childbirth Subdimension of Postpartum SelfAssessment Scale

\begin{tabular}{ccccc}
\hline \multirow{2}{*}{ Scale } & $\begin{array}{c}\text { Possible scores } \\
\text { Min-Max }\end{array}$ & $\begin{array}{c}\text { Intervention Group } \\
\bar{x} \pm \text { SD }\end{array}$ & $\begin{array}{c}\text { Control Group } \\
\bar{x} \pm \text { SD }\end{array}$ & Analysis \\
\hline $\begin{array}{c}\text { Satisfaction with } \\
\text { Childbirth }\end{array}$ & $10-40$ & & & $\mathrm{t}=2,960$ \\
\end{tabular}


Cenkci, Z. \& Nazik, E. (2017). The effect of aromatherapy on pain, comfort and satisfaction during childbirth.

\section{Discussion}

The data obtained from this randomized-controlled study performed to identify the effect of aromatherapy on the pain, comfort and satisfaction during the 1st stage of labor was compared with the related literature.

In the study, it was found that women in the aromatherapy group perceived less pain in the latent, active, and transition phase of the labor compared to the control group. This result shows that "Using aromatherapy during labor reduces the woman's perception of pain at labor" hypothesis is valid. Study supports that aromatherapy during labor is effective in reducing pain. Similarly, study by Burns et al. (2000) reported that lavender is the most effective aromatic agent, aromatherapy reduces the need to use analgesics during labor, and approximately $62 \%$ of women find the oils used to reduce labor pain helpful (Burns, Blamey, Ersser, Lloyd \& Barnetson, 2000). Another study conducted with 156 nullipar women showed that aromatherapy performed using sage (salvia officinalis) is effective in reducing labor pain (Kheirkhah, Vali Pour, Nisani \& Haghani, 2014). In the study by Namazi et al. (2014) which used bergamot oil in labor, and included experimental and control groups, it was reported that the pain intensity was same in two groups, and the pain intensity decreased when dilatation was 3-4 $\mathrm{cm}(p<0,05), 7-5 \mathrm{~cm}(p<0,05), 8-10 \mathrm{~cm}(p<0,05)$ (Namazi, Akbari, Mojab, Talebi, Majd \& Jannesaria, 2014).

Comfort is the expected result with complex structure within the physical, psychospiritual, social, and environmental integrity related to providing help, tranquility, and overcoming problems associated with the needs of the individual (Arslan \& Konuk-Sener, 2009). In the study, it was found that the mean CCQ and subdimension scores at the latent, active, and transition phase of the labor was higher in the intervention group and the difference between the groups was statistically significant. This result shows that "Using aromatherapy during labor increases the level of comfort" hypothesis is valid. Although there is a limited number of evidence-based studies on nonpharmacological methods, as a result of these studies, it was found that non-pharmacological methods are regarded as comfortable by mothers (Yilar-Erkek \& Pasinlioglu, 2016, Mamuk \& Davas, 2010).

Similarly, in the study by Chuntharapat et al. (2008), where they evaluated the effect of yoga training during pregnancy on pain and comfort during labor, the mean CCQ scores of the group which got yoga training was higher than the control group and the difference between the two groups was statistically significant (Chuntharapat, Petpichetchian \& Hatthakit, 2008). In the literature, it is seen that usually women's comfort level at the latent stage of labor is investigated and that nursing care positively affects the comfort level at the latent stage of labor (Pinar, Dogan, Algier, Kaya \& Cakmak, 2009; Capik, Ozkan \& Ejder-Apay, 2014). As there is a limited number of studies on the comfort level during labor, the present study is expected to contribute to the literature in this aspect.

In the present study, when the mean Satistfaction with Childbirth Scale scores of the groups were compared, the mean score of the intervention group was $27,6 \pm 3,6$, and the mean score of the control group was $30,03 \pm 2,53$, and the difference between the groups was statistically significant $(p<0.05)$. This result shows that "Using aromatherapy during labor increases the level of satisfaction" hypothesis is valid. Childbirth, which is seen as a very important experience in the life of women, and the satisfaction of the woman at this period, is very important for the health of the woman and the baby. If the mother is not satisfied with the birth, it can arise many problems. Therefore, it is important to evaluate the satisfaction of the women with childbirth (Capik, Sakar, Yildirim, Karabacak \& Korkut, 2016). In the study by Erenoglu (2013), in which the effect of expressive touching on labor pain and the satisfaction of the mother was investigated using maternal satisfaction scale in normal delivery, it was found that the total evaluation scale scores of the intervention group was higher (experimental group: $148.3 \pm 22.8$, control group: $140 \pm 19.2$ ), and they were more satisfied with the nursing care during labor and were more relaxed (Erenoglu, 2013). In the study by Aktas (2014), which used maternal satisfaction scale in normal delivery, it was observed that women cared by midwives who took empathy training had higher satisfaction levels during labor (Aktas, 2014). When the performed 
studies are evaluated, it can be concluded that quality nursing/midwifery care during labor can increase maternal satisfaction.

\section{Conclusion}

In conclusion, our study results suggest that aromatherapy treatment applied the first stage of labor reduces the perception of pain and increases the level of comfort and satisfaction. Based on these results, as aromatherapy, one of the complementary and alternative methods, is thought to improve nursing and midwifery professions in a professional sense, education on this subject should be provided and in-service training programs should be organized for nurses/midwives, and it is recommended that aromatherapy should be performed through different methods and studies with larger sample groups should be conducted.

\section{References}

Aktas, S. (2014). thesis). Erzurum: Ataturk Universitesi.

Arslan, H. \& Konuk-Sener, D. (2009). Stigma, spiritüalite ve konfor kavramlarinin Meleis' in kavram gelistirme surecine gore irdelenmesi.

l 1

(1), 51-58.

Brown, S. T., Douglas, C. \& Flood, L. P. (2001). Women's evaluation of intrapartum nonpharmacological pain relief methods used during labor. $i$

(3), 1-8.

Burns, E., Blamey, C., Ersser, S. J., Lloyd, A. J. \& Barnetson, L. (2000). The use of aromatherapy in intrapartum midwifery practice an observational study. $\quad r \quad{ }^{2} \quad r \quad$ ff $\quad$ (1), 33-34.

Burns, E., Zobbi, V., Panzeri, D., Oskrochi, R. \& Regalia, A. (2007). Aromatherapy in childbirth: A pilot randomised controlled trial.

$$
\text { ff (7), 838-844. }
$$

Capik, A., Ozkan, H. \& Ejder-Apay, S. (2014). Logusalarin dogum sonu konfor duzeyleri ve etkileyen faktorlerin belirlenmesi. I

Capik, A., Sakar, T., Yildirim, N., Karabacak, K. \& Korkut, M. (2016). Annelerin dogum sekline gore dogumdan memnuniyet durumlarinin belirlenmesi. $\quad l \quad l \quad l \quad$ (2), 92-99.

Chuntharapat, S., Petpichetchian, W. \& Hatthakit, U. (2008). Yoga during pregnancy: Effects on maternal $\begin{array}{llllllll}\text { comfort, labor pain and birth outcomes. } & r & i & r & R & \text { (2), 105-115. }\end{array}$

Erenoglu, R. (2013). I $r$ ff I

(Unpublished doctorate thesis). Kayseri: Erciyes Universitesi Saglik Bilimleri Enstitusu Dogum.

Goodman, P., Mackey, M. C. \& Tavakoli, A. S. (2004). Factors related to childbirth satisfaction.

(2), 212-219.

Karabulut, H. (2014).

$r \quad$ I (Unpublished master thesis). Istanbul: Istanbul Universitesi.

Kaviani, M., Maghbool, S., Azima, S. \& Tabaei, M. H. (2014). Comparison of the effect of aromatherapy with Jasminum officinale and Salvia officinale on pain severity and labor outcome in nulliparous women.

$$
\text { ff } \quad f f \quad i \quad(6), 666-672 .
$$

Mamuk, R. \& Davas, N. I. (2010). Dogum agrisinin kontrolunde kullanilan nonfarmakolojik gevseme ve tensel uyarilma yontemleri. ff $\quad l \quad r \quad r \quad$ 137-144.

Marzouk, T. M., El-Nemer, A. M. \& Baraka, H. N. (2013). The effect of aromatherapy abdominal massage on alleviating menstrual pain in nursing students: A prospective randomized cross-over study.

$r$ 1-6.

Munoz-Selles, E., Valles-Segales, A. \& Goberna-Tricas, J. (2013). Use of alternative and complementary therapies in labor and delivery care: a cross-sectional study of midwives' training in Catalan hospitals accredited as centers for normal birth.

(1), 318-326.

Namazi, M., Akbari, S. A. A., Mojab, F., Talebi, A., Majd, H. A. \& Jannesari, S. (2014). Effects of citrus aurantium (bitter orange) on the severity of first-stage labor pain.

$f f R i$

i $R$

3(3), 1011-1018. 
Cenkci, Z. \& Nazik, E. (2017). The effect of aromatherapy on pain, comfort and satisfaction during childbirth.$$
R
$$

[Online]. 4(2), pp 11-19. Available from: www.prosoc.eu

Pinar, G., Dogan, N., Algier, L., Kaya, N. \& Cakmak, F. (2009). Annelerin dogum sonu konforunu etkileyen $\begin{array}{lll}\text { faktorler. } r & \text { (3), 184-190. }\end{array}$

Potur, D. C., Merih, Y. D., Kulek, H. \& Gurkan, O. C. (2015). Dogum konforu olcegi'nin Turkce gecerlik ve guvenirlik calismasi. ff $\quad l \quad i \quad$ (4), 252-258.

Fakari, F. R., Tabatabaeichehr, M., Kamali, H., Fakari, F. R. \& Naseri, M. (2015). Effect of inhalation of aroma of geranium essence on anxiety and physiological parameters during first stage of labor in nulliparous women: a randomized clinical trial. $\quad$ ff $\quad$ (2), 135-141.

Rashidi-Fakari, F., Tabatabaeichehr, M. \& Mortazavi, H. (2015). The effect of aromatherapy by essential oil of orange on anxiety during labor: A randomized clinical trial. $f f$

i (6), 661-664.

Smith, C. A., Collins, C. T. \& Crowther, C. A. (2011). Aromatherapy for pain management in labour (Review). $i$ $i \quad$ (7), 1-10.

Schuiling, K. D., Sampslelle, C. \& Kolcaba, K. (2011). $\quad r \quad$ i $r \quad$ ff $f f \quad r \quad i \quad f f$ $i \quad i . \quad i \quad f f$ ff $R$. (Edi: Rosamund Bryar, Marlene Sinclair) 2nd Ed. Palgrave Macmillan Publisher, 197-212.

Tasci, K. D. \& Mete, S. (2007). Postpartum kendini degerlendirme olceginin gecerlik ve guvenirlik calismasi.
$\begin{array}{llllll}1 & 1 & 1 & 1 & 1\end{array}$
(2), 20-29.

Tillett, J. \& Ames, D. (2010). The uses of aromatherapy in women's health. $i \quad f f R$ (3), 238-245.

Tournaire, M. \& Theau-Yonneau, A. (2007). Complementary and alternative approaches to pain relief during labor.

(4), 409-417.

Yilar-Erkek, Z. \& Pasinlioglu, T. (2016). Dogum agrisinda kullanilan tamamlayici tedavi yontemleri.
I 1
I
(1), 71-77.

Yildirim, G. \& Sahin, N. H. (2004). The effect of breathing and skin stimulation techniques on labour pain perception of Turkish women. $R$

(4), 183-187.

\section{Appendix}

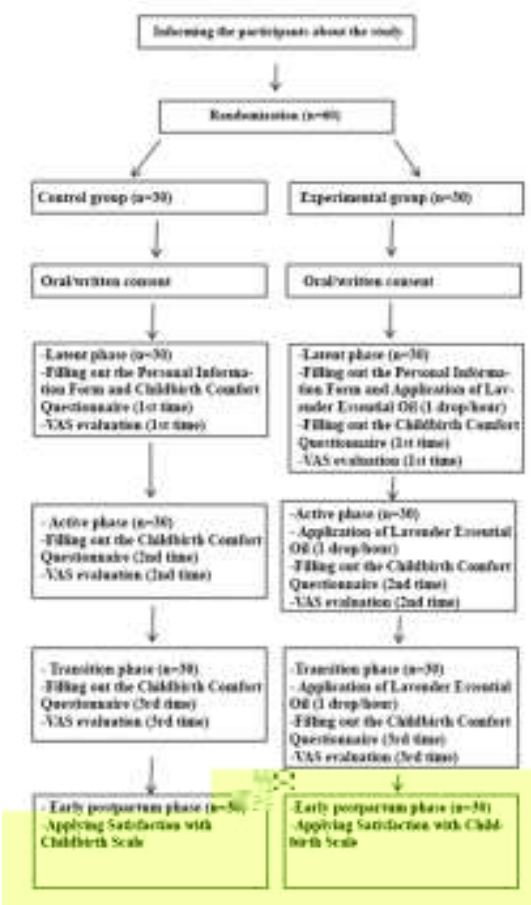

Figure 1. Data collection process 